\title{
META-ANALYSIS ON THE ASYMMETRIC EFFECTS OF OUTPUT IN A MONETARY UNION
}

\author{
MHA. Ridhwan ${ }^{1}$
}

\begin{abstract}
A b st r a ct
The regional impact of the monetary policy has been a crucial issue especially on its distributional impact. Using Meta-Analysis, this paper run a quantitative survey on previous studies to explain the the asymmetric impact of national policy on economic growth across region. Based on selected criteria we have similar researches on sample data; mainly they used VAR method.

Our model estimation shows the significant and importance of capital intensity degree, the financial depth and several macroeconomic indicators in explaining the different result across region and period of these studies. In general our finding confirms the robustness of their result.
\end{abstract}

Keywords: Monetary union, output, Meta-Analysis

JEL classification. E52, R11, C83

1 The author is an economist of Bank Indonesia, and currently being a PhD candidate at the VU University Amsterdam and Tinbergen Institute, Netherlands. Email: mha_ridwan@bi.go.id. With the usual disclaimers I thank Piet Rietveld, Peter Nijkamp, Henri L.F. de Groot for thorough supervisions, and Patricia Stekelenburg for excellent research assistance. Ame Trandem has generously edited this manuscript. The earlier version of this paper has been presented in NARSC Meetings in Brooklyn, NY-USA, November 2008; and ERSA Conference, Lodz-Poland, July 2009. 


\section{INTRODUCTION}

"Though many macroeconomists would profess little uncertainty about it, the profession as a whole has no clear answer to the question of the size and nature of the effects of monetary policy on aggregate activity" (Sims, 1992).

The impact of monetary policy on the real economy has been a contentious area in macroeconomics. The quest of ' $w$ hat is inside the black-box'2 conventionally posits whether changing interest rates have impact on real economic variables, ${ }^{3}$ and if so, how powerful these effects may be.

The debate of monetary transmission is even more pronounced when looking at the regional dimension, ${ }^{4}$ as monetary policy is inherently addressing a national target, while different regions within a monetary union exhibit different structures and characteristics. Hence, they may respond asymmetrically to the impulses of uniform monetary policy. As a consequence, it will have different distributional implications across regions; the economic activity in a core region may be stimulated by the policy, while the periphery may become more depressed. ${ }^{5}$

The distributional effects of a common monetary policy up to now still draw attention and raise concerns from policymakers and academia, particularly after the advent of the European Monetary Union (EMU) in 1999. Despite some good hopes from the unification, it may also induce fears that potentially lead to economic divergence across the participating economies. ${ }^{6}$

To unravel this issue, numerous studies have attempted to examine regional effects of monetary policy. For instance, Carlino and De Fina (CD) (1998, 1999), and Owyang and Wall (OW) (2004) have looked at the USA; while Ramaswamy and Kloek (1998) and Clements et al (2001) have studied European countries. In general, their findings suggest differential output effects in response to a common policy shock.

2 Bernanke and Gertler (1995) introduce the term "black box" to point-out puzzles in the results of monetary transmission studies.

3 Interest-rate channel is the conventional way in which monetary policy is presumed to operate in a large, fairly closed economy with a developed financial system. Other monetary transmission channels that are normally found in monetary policy literature are the bank-lending, exchange rate, expectation, and asset-price channel (see, for instance, Mishkin, 1995, 1996).

4 The traditional neoclassical approach has ruled out the role of money in economic development particularly in the long run (known as long-run monetary neutrality).

5 Ridhwan et al. (2008) among others have surveyed links between monetary policy and regional development, and they discuss implications of common policy for core and peripheral regions.

6 The EMU area closely refers to theory of Optimum Currency Areas (OCA). The OCA theory essentially asserts a prerequisite for participating economies to have symmetric impacts given the common macroeconomic policy. Even if some of them experience asymmetric shocks, the availability of some adjustment mechanisms would safeguard to correct some potential imbalances within the economy, notably through flexible factor markets i.e. high factor mobility and adjustable factor prices; as well as automatic fiscal stabilizers. 
Other studies especially on European countries have concluded that the output effects in the Euro area are very similar (see, for example, Peersman, 2004). Gerlach and Smets (1995) and Kieler and Saarenheimo (1998) conclude that there is little or no difference in the monetary transmission across the countries. These conflicting findings tend to indicate that there are still far reaching agreements of whether the "one-size-fits-all" policy may generate asymmetric effects across regions. ${ }^{7}$ In some cases, size and time-path of the output effects are found to vary largely across studies. ${ }^{8}$

Given this state of affairs, our study attempts to revisit and discuss the unresolved issue by providing a quantitative survey using a methodology known as meta-analysis. Florax et al. (2002) have argued that the method constitutes a more systematic approach towards analyzing the sources of (quantitative) variation in previously obtained research results, and hence could be useful in applied economic policy analysis such as this monetary transmission study.

De Grauwe and Storti (GS) (2004) examine the effects of monetary policies on real variables across countries, and found that methodological differences across studies significantly contribute to the variation of monetary impacts. Having employed the same technique, Pitzel and Uuskula (2005) using only a small sample conclude that monetary transmission in European countries is strongly influenced by financial depth and structure. ${ }^{9}$

Compared to earlier studies, this paper extends their analysis in several ways. First, in order to deal with comparability issues, our sample is restricted to studies which only employ the Vector Autoregressive (VAR) methodology ${ }^{10}$, and uniformly report the effects of a contractionary monetary shock (as measured by one-percentage increase of interest rate) on

7 The terminology of asymmetry in monetary study may be more related to the different output impacts of a tight and easy monetary policy. Cover (1992) presents an early evidence of the asymmetric effects that positive money-supply shocks have no effect on output, whereas negative money-supply shocks cause output to decline. Other studies by De Long and Summers (1988); and Karras (1996) on the US and European economies also suggest that real output is relatively more sensitive to negative than to positive monetary shocks. Holmes (2000) provides a survey of the asymmetry by distinguishing the output effects of negative and positive monetary policy within the UK regions. In this study, we use the notion of asymmetry in order to highlight differential effects of monetary policy (measured by a $1 \%$ increase of interest rate) on output across regions and countries.

8 Also, Guiso (1999) asserts the shocks to the model specifications typically differ across European countries (which variables included and how shocks are identified), that are reflected both in terms of size and time path. Mojon and Peersman (2001) stated that evidence of cross country differences in transmission brought by any single paper is not robust across studies, that is partly because of size of the estimated monetary policy shock differs across the EU countries. Given the robustness issue, Peersman (2004) rejects the argument that monetary policy undertaken in the Eurozone has generated heterogenous impacts.

9 Other related surveys were carried out by Cechetti (1999) and Elbourne and de Haan (2004), using different research methods. The first author asserts differences in legal systems have played key-role in different monetary transmissions across European countries, while the latter found a little correlation between legal systems and financial structure that may cause the differences in monetary transmissions.

10 Having focused on analyzing a similar model across studies, we expect to minimize the chance that the differential effects of monetary policy might arise from methodological differences rather than from economic differences. Besides, the problem of "comparing apples to oranges" that commonly arised in meta-analysis, especially in economics could be eluded.. 
output. ${ }^{11}$ Second, it exploits a wider weighting scheme in meta regression models in order to capture the study-heterogeneities. Third, a broader set of conditioning variables has been introduced in order to find potential variables that are able to in explaining variation of the output effects, and its selection is anchored in the existing theory. Finally, our study puts more emphasis on the output effects at a regional level rather than at a country level. ${ }^{12}$

The remainder of the paper is organized as follows. Section 2 will discuss briefly the relevant theoretical background and typical monetary transmission channels. Section 3 describes the structure of the meta-analysis sample, data and model specification. Section 4 provides a meta analysis of the role of study characteristics and other important factors that may explain variation in the estimated effects of monetary policy on output. The next section investigates differences in monetary transmission across regions, and then attempts to draw typical trajectories of output development. The final section concludes.

\section{THEORY}

Conventional economic models have explained how monetary policy may influence the real economy through the aggregate demand side and therefore, the interest rate has long been known as the most prominent transmission channel. An increased interest rate leads to increases in the cost of capital (direct effect). This in turn leads to a fall in the interest-sensitive components of aggregate demand (indirect effect). An increase in short-term interest rates reduces in the prices of assets, which in turn reduces consumption expenditure through wealth effects, and investment expenditure through Tobin's q-effects.

Another important channel in which a tightening of monetary policy tends to depress economic activity is the credit channel. In the credit view, the contractionary effects of monetary policy are transmitted to a large extent through a lowering in bank lending. Also, the exchange rate channel of monetary policy is crucial particularly in small open economies. The monetary tightening affects the nominal exchange rate to appreciate, while nominal rigidities occurs in the short-run, and thus it leads to the appreciation of the real exchange rate. In turn, this may squeeze net exports. ${ }^{13}$

11 While the real effects of monetary shock on price are also important, however the focus of this paper only limits to the output reponse following a monetary shock. Additionally most of studies reveal that the price effects of monetary policy tend to puzzle, that is known as 'price-puzzle'.

12 Regional area mentioned here, could be classified in a narrow sense such as states or provinces under one sovereign country that shares a national monetary policy; or, in a broad sense, as a collection of independent countries that is united under a monetary union such as in the Eurozone. While, the GS study is based on a country level.

13 Since monetary transmission mechanism is quite intensively discussed in the standard monetary or macroeconomics text books, for brevity we limit discussion on this topic (further details see, Mishkin, 1995, 1996 ; Taylor, 1995 among others). 
Meanwhile, some researchers alternatively have shown the importance of supply-side or cost-side effects of monetary policy, such as Blinder (1987), Christiano et al. (1997), and among others. An increase in the nominal interest rate may have an output effect primarily through increase in production costs notably via working capital channel (for more details, see Barth and Ramey, 2001). Broadly speaking, a contractionary monetary policy may also lead to an output decline from the supply-side or cost-side effect. ${ }^{14}$

From an empirical point of view, Vector Autoregressive (VAR) models have been widely used to study the transmission mechanism of monetary policy (see the surveys by Leeper et al., 1996 and by Christiano et al., 1999). The VAR has several advantages; as all the variables are treated symmetrically, hence no requirement to split between exogenous and endogenous variables (Sims, 1980, 1986; Bernanke, 1986). In a regional context, some recent analyses for instance Carlino and De Fina (1999), Fratantoni and Schuh (2003), adopt the VAR model to allow for spillover effects between regions.

In principle, a VAR consists of a set of equations in which each variable in the system is determined by its lagged values and the lags of all the other variables in the system. The VAR can be represented in the following moving-average representation ${ }^{15}$ :

$$
B(L) y_{t}=u_{t}
$$

where, $y_{t}$ is a $3 \times 1$ vector consisting of the log differences of the price level, output and the level of the short-term interest rate. $B(L)$ is a polynomial in the lag operator with $3 \times 3$ matrix coefficients. Shocks to the system, $\varepsilon_{t}{ }^{p}, \varepsilon_{t}{ }^{y}, \varepsilon_{t}{ }^{i}$ are represented by the vector $u_{t}$. Then $B(L)=$ $I-B^{1} L^{1}-B^{2} L^{2}-\ldots B^{\prime \prime} L^{\prime \prime}$; where $n$ is the lag length of the VAR. One of the most relevant features is its impulse-response function that summarizes the dynamic interactions between variables, for example between prices, output growth and interest rate (as a policy shock) as specified above. Moreover, Cochrane (1998) emphasizes that the impulse-response functions capture history, the average values of some relevant economic variables following a monetary policy shock. To have a better understanding of the VAR applications across monetary studies, the next section discusses an application of meta-analysis in this area.

\footnotetext{
14 Next, if the shock leads to the increasing of prices, demand may respond in the opposite direction, then output will be falling down in a contemporaneous way. Therefore, the policy shock may have both supply-side and demand-side effects. Barth and Ramey (2001) in following emphasize that within this line of thinking, the concept of non-neutrality of money may prevail due to some type of rigidity.

15 More details about the VAR methodology can be found in a standard Time-Series Econometrics text books, such as Hamilton (1994) and Enders (2004).
} 


\section{METHODOLOGY}

Meta-analysis was first proposed by Karl Pearson in 1904. It refers to the statistical analysis of a large collection of results from individual studies for the purpose of integrating the findings. Simply put by Stanley and Jarrell (1989), the method is the analysis of empirical analyses that attempts to integrate and explain the literature about some specific important parameter. As later emphasized by Florax et al. (2002), meta-analysis provides the researcher with a tool to compare and/or to combine outcomes of different studies with similar set-ups (or, alternatively, differences in set-ups that can be controlled for). ${ }^{16}$

Initially meta-analysis was frequently used in medical sciences and the first book-length publication was Extra-sensory perception after sixty years, authored by Duke University psychologists J. G. Pratt, J. B. Rhine, and associates (Bosch, H, 2004). Nowadays it enjoys its widespread use in many areas, including psychology, social sciences, marketing, education and economics in particular. Stanley and Jarrell (1989) have begun the application of meta-analysis in economics, and later were rapidly followed by others, for instance Card and Krueger (1995) in labor economics, Smith and Huang (1995) in environmental economics, and Nijkamp and Poot (2004) in macroeconomics of fiscal policy.

In macroeconomics and monetary economics in particular, several studies have also attempted to apply meta-analysis to identify, for example, the effect of currency union membership on bilateral trade by Rose and Stanley (2005), and the income elasticity of money demand by Knell and Stix (2005).

The application of meta-analysis is therefore also well-suited for this study in analyzing study-differences found a large variation of output elasticity across regions or countries within a monetary union. It may also reap the main benefit of the method that is basically a statistical by nature: it may give more powerful estimates of the true effect size (and perhaps better findings) than other approaches such as narrative literature reviews or vote-counting reviews. As pointed out by Stanley (2005), the latter approach suffers from several problems such as methodological bias and questionable decisions or controversial results. ${ }^{17}$ Above of all, Florax et al. (2002) posits that meta-analysis is less prone to 'subjectivity', and it can help explain the abundant variation in empirical estimates often'encountered in empirical research.

16 For technical aspects of the meta-analysis method, see e.g., Sutton et al., (2000).

17 Although those problems may also arise in meta-analysis, but in general they are more severe in the narrative reviews or votecounting. 


\section{III.1. Meta-Regression Model}

The general specification of our meta-regression model is as follows.

$$
Z_{j}=\alpha+\sum \beta_{i} X_{i j}+\sum \gamma_{i} Y_{i j}+\varepsilon_{j} \quad \mathrm{i}=1,2, \ldots, K ; \mathrm{j}=1,2, \ldots ., L
$$

Where $Z_{j}$ represents the percentage change in effect size due to one-percentage increase of the interest rate in study $j$. Since we have specified four parameters of the effect size namely maximum level, the fourth quarter, the sixteenth quarter and time-elapsed at the maximum, accordingly we can generalize the above model into four different model specifications as well. Previously we have discussed two meta independent variables, referring to study-characteristics $\left(X_{i j}\right)$ and conditioning variables $\left(Y_{i j}\right)$ respectively. $\alpha, \beta$, and $\gamma$ are parameters to be estimated, while $\varepsilon$ is the error term.

The model will be estimated in four ways. The first approach is to use the ordinary least square (OLS) estimator. As pointed out by White (1984), however, the OLS standard errors may be wrong in the presence of region/country-specific heteroscedasticity or region/country-pairspecific contemporaneous correlation of the errors, and thus its estimator may be inefficient. ${ }^{18}$ Since both of those phenomena potentially persist in our data, thereby we employ robust standard errors or Huber-White standard errors, in order to correct simultaneously for the heteroscedasticity and cluster autocorrelation problem. ${ }^{19}$ By and large, this method does not change coefficient estimates but does improve the estimation of standard errors. In some recent meta-studies, the application of Huber-White approach can be found for instance in Gorg and Strobl (2001), and Abreu et al. (2005) among others.

Next, it is our main concern to check robustness of regression results that are previously specified by utilizing some weighting schemes. This approach may also be relevant in the view of different studies/publications are characterized by some endowment differences, notably study-quality and some unobserved variations. ${ }^{20}$ In so-doing, we rely upon the weighted

18 Region/country-pair correlation problem may arise due to say, between Germany and Netherlands may have special economic ties, or similarly between New York and Michigan state in USA.

19 Cluster autocorrelation refers to the observations which are independent across clusters (groups), but not necessarily independent within clusters

20 Wolf (1986); Weichselbaumer and Winter-Ebmer (2005); Knell and Stix (2005) provide some discussions and applications of how meta-regression should be weigthed. In contrast, Krueger (2003) rejects the way of weighting studies such as by number of estimates, and as instead he proposes an equal weighting as the more appropriate approach.

21 For regressions with cross-section data, typically it is assumed the error terms are uncorrelated, while in econometric theory it is also known their variances are not constant across individuals (heteroskedastic problem). Otherwise, such problem creates the OLS estimators are no longer efficient (minimum variance), thus the $t$ and $F$ tests based on them can be highly misleading, resulting in erroneous conclusions (Gujarati, 2003; Kennedy, 2008). Furthermore, WLS is applied if true variance is known. If it is not known, 
(generalized) least squares (see Gujarati, 2003; Greene, 2000). ${ }^{21}$ Weichselbaumer and WinterEbmer (WW) (2005) also apply this technique in a meta-analysis study, later they add that the adoption of a particular weighting scheme is aimed to deal with the lack of independence across multiple estimates that are available for each study. ${ }^{22}$

In order to deal with variations in the study-quality, while simultaneously evade a possibility of selection bias given subjective choice by a researcher ${ }^{23}$, this paper assigns weight to the studies based on journal ranking reported in Kalaitzidakis et al. (2003). Then, we re-checked it by referring to The Tinbergen Institute's ranking. ${ }^{24}$

Next, we also assign the square root of the degrees of freedom as an alternative weight to account a precision degree of the estimates, since the absolute value of $t$-statistic can not be found in our case. ${ }^{25}$ The last weight used is sample size that refers to number of regions or countries used in each of study.

Furthermore, since the underlying method of our meta-study here is based on the crosssection regression method, we average data of the explanatory variables especially conditioning variables. Accordingly the time dimension for the averaging will be adjusted to the time span in the study. This approach is easy to carry out and it minimizes the chance that the results depend on the data for a particular year, and it also helps control for business-cycle dynamics. ${ }^{26}$

\section{III.2. Meta-Data and Explanatory Variables}

There are quite large and extensive studies of how monetary policy affects regional economies as well their responses to the common policy shock. To collect empirical studies in the monetary transmission area that are becoming as our sample, we follow a standard approach and thus, resorts to the Econlit (Economic Literature Index), that is widely known as a popular and easily accessible research database.

Initially the relevant studies are searched in this database, simply by typing the following keywords as any reference to: '(monetary policy*, or macroeconomic policy*), (output*, or

one can rely on interalia, the Huber/White/sandwich estimator. However, Greene (2000) proposed alternative estimators such as two-step GLS (generalized least squares) and maximum likelihood, since the ordinary method may not perform well if the general heteroscedastic regression model has too many parameters to estimate.

22 The notion of lack of independence refers to existing studies of different authors might have used the same or very similar data but different methods, hence raises concerns that they are not drawn from random sample.

23 GS mention the issue of selection bias related to study-quality, where the length of the sample periods of the primary studies is used as a proxy.

24 Visit http://www.tinbergen.nl/.

25 Based on sampling theory, it is widely known that the absolute value of the t-statistic would be proportional to the square root of the degrees of freedom in the regression.

26 CD (1999) has initially raised this argument. 
growth*) and (region*, or country*)'. So far, the Econlit search led us to 42 studies in total.

However, since all the studies found tend to show large differences in many aspects, thereby in order to have a proper meta-analytical approach, we need to impose some selection criteria for those studies. First, the methodology employed in the studies is the vector autoregressive (VAR) method that gained its momentum in the early 1990's; while previously most studies relied on small structural models and reduced form equations. ${ }^{27}$ It is widely known that the state of the art methodology shows some robustness features particularly in identifying role of monetary policy and other types of shocks that may implicate economic activity (see Faust, 1998; Elbourne and de Haan, 2004).

Second, the selected studies describe regional responses to a contractionary monetary policy shock in terms of the percentage output change due to one-percentage point or 100 basis points of unanticipated interest rate increase. ${ }^{28}$ This facilitates us later in comparing econometric results across samples, as it indicates a semi elasticity relationship Simultaneously, they are able to show timing effect of the monetary actions. It is our focus here only to examine the contractionary effect of monetary policy on output. A comprehensive survey by Florio (2004) indicates that the reduction in output following a negative monetary policy shock appears larger than the expansion induced by a positive shock of similar size. In general, as predicted by theory that monetary policy tends to be more effective in spurring economic activity during recession period rather than during upswing one.

Based on the selection criteria, we then have collected a good number of studies, that led us to around 285 sample observations, which are mostly published in some well-known journals and/ publications (working papers). The typical output response due to the monetary shocks based on the VAR model is shown by Impulse Response Functions (IRF). ${ }^{29}$ As an illustration, we show in Figure 1 below some common patterns of the output effects and time paths, which are re-sketched from the impulse response function (IRF) graphs of our samples. By and large, the curve shapes mainly exhibit the fall of regional output growth after an unanticipated increase of one percentage point in the central bank (short term) interest rate. ${ }^{30}$

27 See, for example, Fishkind, 1977; Miller, 1978; Garrison and Chang 1979 among others. Due to this criteria, we should ignore studies that utilize other than VAR. Therefore, unfortunately we lose more than half of the initial articles collected.

28 As previously mentioned, the VAR also allows other channels of monetary shocks to the economy, such as credit channel and exchange rate channel. However, we restrict to our analysis here to the most conventional channel i.e. interest rate, that is known has direct effects to output development and also used by central banks as its main policy instrument. While, further digressions of those other channels lays outside of the scope of this paper.

29 The VAR study typically reports feedback effects of shock innovations through the graphs of Impulse Response function (IRF).

30 However, it is worth noting that the output pattern tends to show somewhat small positive responses in the early period of the policy shock, as what the standard monetary theory asserts that monetary policy typically has time-lag effects (further details, see Walsh, 2003). 
Our next step is to derive effect-sizes from the IRF graphs, and specifically our interests are four point-estimates of effect size related to output and time effects. ${ }^{31}$ The output effects refer to the maximum level, the level at the fourth quarter, and the level at the sixteenth quarter; while the time effect pertains to time-elapsed at the maximum effect.

The maximum effect measures the peak (largest) impact of the monetary shock (in absolute term) and denotes to the lowest point of the graph. The fourth-quarter observation may become a proxy measure for short-run effect, while the sixteenth-quarter effect may be a representative for medium-run effect. ${ }^{32}$ The time-estimate extracted may also be useful to highlight speed of the policy shock before reaching maximum level (for more details, see Subsection III.4). In the meta regression analysis, all four effect size types will be used as meta-dependent variables.

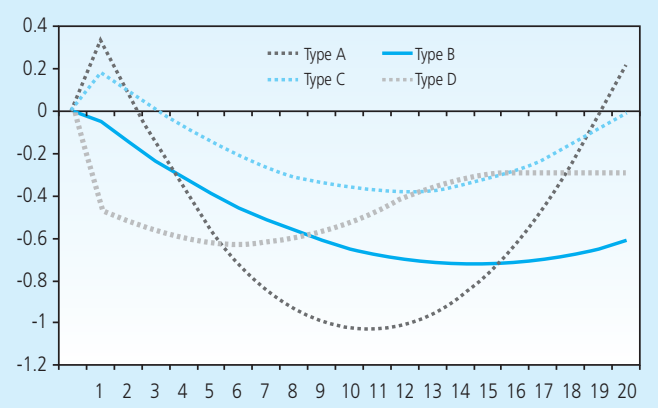
Figure IV.1 Some common patterns of the IRF graphs describing size and timing of output effects of monetary actions (reproduced from primary studies).

The explanatory variables in meta analysis can be distinguished in 'primary study features' and 'conditioning' variables. The first variable mentioned can be categorized into'type of model specification, structure of the data and time characteristics as discussed below. '

Restriction type (identification issue) - The VAR modeling offers many flexibilities especially in defining identifications and imposing restrictions. To account for these differences across

31 Since we need to recover estimates from the IRF graphs, therefore the graph sizes in the underlying studied have been expanded to allow us to extract the highest precision of the estimates. To do this, we did comparative checks by reserving around 20 percents of estimates found in primary studies that report the size effects altogether with the IRF's VAR. Then, we use them as our control estimates to verify whether coefficients obtained from the graphs are imprecise. However, the results confirm that the first technique generally produces similar coefficient magnitudes relative to the ones reported in the studies.

32 The sixteenth quarter is selected as a measure for medium-run effect. However, GS (2004) used the fifth year (= $20^{\text {th }}$ quarter) as a measure for the long-run effect. As predicted by theory, money tends to be neutral in the long-run, hence rather than falling a foul within this debate, hence we consider for both short-run and medium-run effect only. Additionally, the long-run impact model tends to vary substantially across studies, is mainly stemmed from the fact that some studies impose a long-run restriction, or known as the Structural VAR. 
studies, we distinguish between five different types of identifications, viz. the basic VAR based on Choleski decomposition and a recursive identification scheme (based on Sims, 1980). Since this model does not impose any structural restrictions from a particular economic theory, it solely depends on and "let the data speak themselves", hence thereafter is known as an atheoretical modeling.

The second type of restrictions utilizes non recursive decomposition and imposes some variables can not contemporaneously affect each other. For example, a shock to the interest rate has no contemporaneous effect on output, or there is a lag-period (Bernanke and Blinder, 1992). Another type is a long run a priori theoretical restriction to identify economic structure from the reduced-form (Blanchard and Quah, 1989; Shapiro and Watson, 1988). ${ }^{33}$

Meanwhile, an identification scheme by Gali $(1992,1999)$ attempts to mix the short-run (contemporaneous) and the long run restriction altogether. ${ }^{34}$ Finally, the dynamic specification of VAR also allows King et al. (1991) to use a cointegrated model, where all the variables has different stationary degree but some linear combinations of the variables are stationary. The cointegration can be tested for with the Johansen technique. ${ }^{35}$ Next, in presenting our regression results, for simplicity all these restrictions are called as vara, varb, varc, vard, and vare respectively.

Model dimension - The dimension of the VAR systems is basically based on number of (explanatory) variables. Its introduction in our model is motivated due to the fact that different models across studies use different dimensions in order to represent different economic structures and different reaction functions across countries and regions. We take into account their differences across studies by assigning a separate dummy variable, and they can be distinguished as follows. The first type is a standard dimension consisting of a four variable system of prices, output, interest rate, and money. Another variant adds an exchange rate variable, and the last variant includes exchange rate, oil (commodity) price and foreign interest rate to the standard dimension.

Data characteristics - This study employs different dummy variables for observations that use different measures for the output effects of monetary policy. The output measures used depend on geographical location of the studies; USA studies mainly employ state personal income, while European studies either use Gross Domestic Product (GDP), or the industrial

33 A long run restriction usually takes the form that a shock to one variable has no long run impact on another, therefore monetary shocks should have no long run effect on output because monetary neutrality holds.

34 This scheme also identifies technology shocks as the only shocks that have permanent effects on productivity, in other words monetary policy shocks have no long run effect on output.

35 For more details of discussions of restrictions and identifications in VAR model can be found in Enders (2004) and Favero (2001) among others. 
production index (IPI). ${ }^{36}$ Variation of short-term interest-rates used such as the central bank rate, or money market rate will also be captured by a dummy variable.

Temporal characteristics -Temporal variation across the sample is taken into account and classified as follows. Following an eclectic approach, we have listed some measures that potentially represents the time dimension of the data: the mid-point of the sample period, initial year of the sampling, end of period of the sample, time-length of the sample period and dummy in decade i.e. 1960's, 1970's, 1980's and 1990's onwards. ${ }^{37}$ Meanwhile, we also take into account differences in time-lag length in our sample. Finally, time-unit of the data used across studies such as quarterly and monthly data is distinguished by assigning a separate dummy variable.

The second group of explanatory variables in the meta-analysis are conditioning variables. Basically they are a set of control variables that are aimed to capture other relevant factors beyond consisting of macroeconomic and financial variables as well as characteristics for geographical location. ${ }^{38}$

Share of manufacturing and construction sector to GDP - This measure is commonly used to represent capital intensity (see Schunk, 2005). Hence, it may be a good proxy to capture the economic structure of a particular region, in that it highlights the amount of capital utilized with respect to other production factors, such as labor. ${ }^{39}$

Financial variables - As predicted by theory, financial variables may affect variation in the strength of monetary transmission across geographical location. Cecchetti (1999) employed several financial indicators to highlight the role of financial structure in explaining differential monetary effects across European countries. Following his approach, this study employs ratio of stock-market capitalization to GDP as a measure for the availability of alternative finance.

Meanwhile, some other studies employ the level of financial development in explaining variation in cross country growth. Having reflected on this approach, in order to capture variation of financial deepening across regions we employ the number of bank-offices (per 100.000 people) and the ratio of the credit to private enterprises over GDP respectively. The latter indicator

36 For simplicity, next we will use GDP as a representative for other measures.

37 The last variable is refered to De Grauwe and Storti (2004).

38 The set of macroeconomic and financial variables are incorporated as explanatory variables (simultaneously with other variables) in our regression models in order to shed lights on why there are large variations of output elasticity across studies. Based on the simulations by Koetse et al. (2005) and Keef and Roberts (2004), Abreu et.al. (2005) have argued that although in many metaanalyses the specification of the conditioning variables is dealt with rather casually, they show a meaningful and statistically unbiased comparison. The data-source of these conditional variables are from PWT 6.2., WDI, EU KLEMS, BEA and OECD main economic indicators.

39 Some studies, however, only resort to share of manufacturing sector in the economy. Nevertheless, we follow the first approach, as construction industries belong to the capital intensive sector, and thus may be relatively sensitive to monetary changes. 
has been considered by King and Levine (1993) and Levine, et al. (LLB) (2000) as a measure of level of financial development. ${ }^{40}$ We follow LLB in using private credit as our preferred measure of financial development. This is the value of credits by financial intermediaries to the private sector, divided by GDP. This type of credit is the preferred measure because it excludes credit granted to the public sector and credit granted by the central banks and other government banks.

Economic size - This measure based on total value of gross regional domestic products (GRDP) or, GDP (at the country level)-in US Dollars. We employ this measure due to the fact that there are economic size differences amongst regions or countries of our observation. An alternative measure for the size is number of inhabitant. However, we prefer to select the first measure as it concerns an economic value..$^{41}$

Share of exports to GDP - This measure is based on share of trade in goods and services relative to total GDP. This measure is commonly used to represent the degree of openness of a particular country or region.

Several studies have discussed how differences in openness could be important in explaining regional variations in response of monetary policy shocks. Consider the impact of monetary tightening which would result in a general slowdown of domestic activity, yet regions that earn a large part of their revenues from overseas would experience some shielding from direct interest rate effects, so the impact may be less strong. Therefore, a region that is relatively more export orientated would be less likely affected by the interest rate shocks, and vice versa. However, overall evidence from the existing literature tends to be inconclusive. ${ }^{42}$

Geographical characteristics - This paper considers regions and countries under a monetary union simultaneously, where the latter are independent or sovereign countries that are characterized with some specific characteristics, namely institution, language and culture. ${ }^{43}$ For this reason, we assign a separate dummy variable to distinguish our observations between regional (state) and country level.

40 Because of data availability at regional level across countries, we could not include all variables to capture financial structure used by Cechhetti (1999). Different concepts for small bank-loans and firm-size between USA and European countries also limit us to employ them as our explanatory variables, that are commonly found in monetary transmission studies.

41 The advantage of introducing both population and GDP as explanatory variables would be that implicitly the contribution of GDP percapita can be accounted for.

42 Meanwhile, Frankel and Rose (1996; 1997) examines role of exchange rate regime in affecting OCA criteria, then argue that having a fixed exchange rate will cause trade relations to be more intense within countries in EMU area. Later they conclude that countries with closer trade links tend to have more tightly correlated business cycles. Nevertheless, as previously indicated that our study gives more emphasis on an interest rate channel which has direct effect rather than indirect channels such as the exchange rate channel.

43 While, a standard literature asserts the specific characteristics in regions within a country tend to be more similar, or less fragmented. 


\section{RESULT AND ANALYSIS}

\section{IV.1. Descriptive statistics}

Before turning to the meta regression analysis, we discuss briefly some descriptive statistics of four different measures of the size and time dimension of the effects with reference to Figure IV.1. As aforementioned, they are obtained from the IRF of the studies that correspond to the declines in output after a contractionary monetary policy. In general, the sample of observations recovered from the studies tends to show a large variation of the estimated output elasticity.

Figures IV.2, IV.3, and IV.4 show the output effects at the maximum level, the fourth quarter, and the sixteenth quarter respectively following a contractionary monetary policy. In the first figure, the mean of maximum impact is $0.76 \%$, so a one-percentage point increase of interest rate will be followed by $0.76 \%$ maximum output decrease on average.

Next, the sixteenth quarter measure as a proxy for medium-term effect (as shown in Figure IV.3) declines around $0.50 \%$ following a one-percentage point increase of the interest rate. Figure IV.4 represents the fourth quarter (proxy for short-term effect); the mean output effect will decline $0.31 \%$. In order to check average significances in the three measures, we use a standard statistical method namely a simple $t$-test to do so, and its results indicate they are statistically different from zero. ${ }^{44}$

Based on the Jarque-Bera statistic, we find that the parameter distributions of those figures are not normally distributed. More details of descriptive statistics of these four measures can be found in Appendix IV.1.

Finally, Figure IV.5 depicts that the mean of time elapsed to reach the maximum effect due to the shock is about 8 quarters (two years). Similar to the previous approach, we find that the $t$-test implies that this value of 8 quarters is statistically different from zero. Other additional tests indicate they are not normally distributed.

\section{IV.2. Estimation Results and Analysis}

We continue by presenting meta-regression results that are classified based on previous specifications such as the maximum effect, the fourth quarter, sixteenth quarter-effect and time elapsed at the maximum effect. From the table 1 below, we summarize the most important findings of regressions as follows. ${ }^{45}$ 


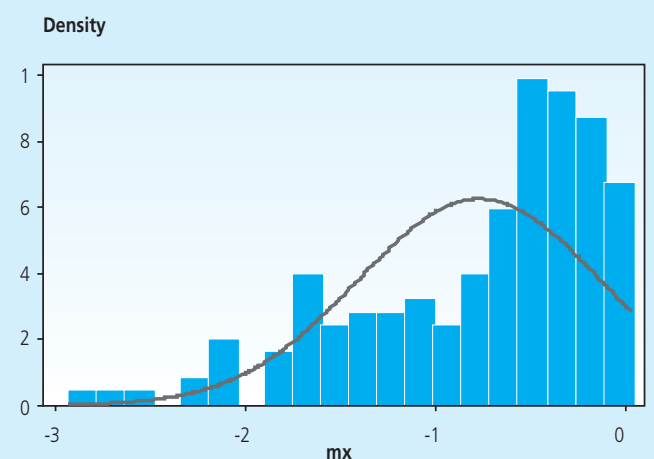

Figure IV.2

Histogram of output effect due to one percentage point increase of interest rate at maximum level $(\mathrm{mx})$

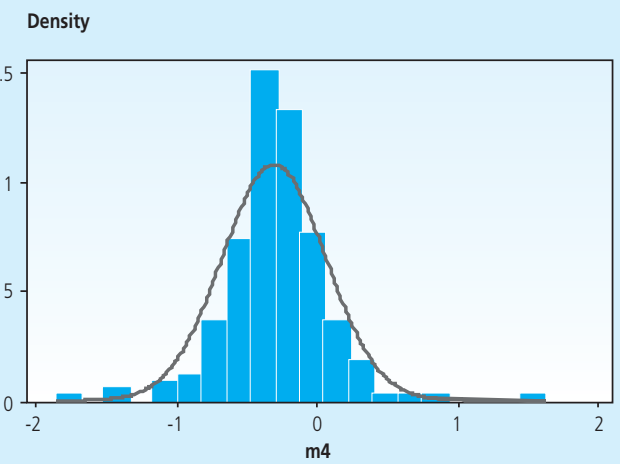

Figure IV.4

Histogram of output effect due to onepercentage point increase of interest rate in the fourth quarter $(\mathrm{m} 4)$
Density

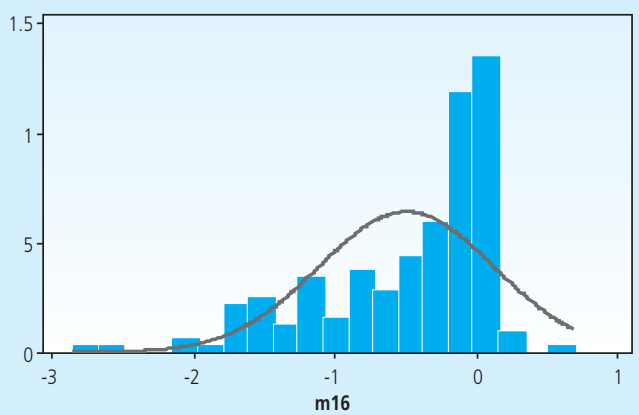

Figure IV.3

Histogram of output effect due to onepercentage increase of interest rate in the sixteenth quarter (m16)

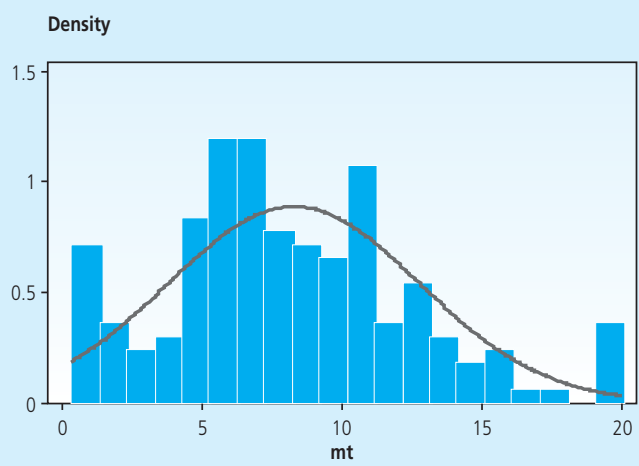

Figure IV.5

Histogram of time-elapsed at maximum effect (in quarters) of the policy shock (mt).

The first and most striking finding is that the share of the manufacturing and construction sector in GDP has a significant positive effect (in absolute term) in all different specifications. This means that economies with a large capital intensity are more sensitive to an interest rate increase, and also that the duration of the impact is longer. Second, the share of credit to GDP as proxy for level of financial development indicates a positive and significant effect. 


\begin{tabular}{|c|c|c|c|c|}
\hline Meta regre & n estima & $\begin{array}{l}\text { Table IV.1 } \\
\text { ased on the }\end{array}$ & LS robust star & dard errors \\
\hline Meta-independent & & Depe & ndent variables & \\
\hline variables & $\begin{array}{l}\text { Maximum } \\
\text { effect }(\%)\end{array}$ & $\begin{array}{l}\text { The fourth } \\
\text { quarter effect }\end{array}$ & $\begin{array}{l}\text { The sixteenth } \\
\text { quarter effect }\end{array}$ & $\begin{array}{c}\text { Time-elapsed at maximum } \\
\text { effect (in quarters) }\end{array}$ \\
\hline $\begin{array}{l}\text { Share of manufacturing and } \\
\text { construction sector to GDP (\%) }\end{array}$ & $\begin{array}{r}-0.0200^{*} \\
(-2.27)\end{array}$ & $\begin{array}{r}-0.0176^{* \star *} \\
(-3.59)\end{array}$ & $\begin{array}{r}-0.0271 * * * \\
(-3.35)\end{array}$ & $\begin{array}{r}0.0174^{*} \\
(2.22)\end{array}$ \\
\hline Share of credit to GDP (\%) & $\begin{array}{r}-0.00773^{*} \\
(-2.56)\end{array}$ & $\begin{array}{r}-0.00412^{*} \\
(-2.29)\end{array}$ & $\begin{array}{r}-0.00463 \\
(-1.58)\end{array}$ & $\begin{array}{r}0.0136^{* *} \\
(2.93)\end{array}$ \\
\hline Size of GDP & $\begin{array}{r}0.136^{* * *} \\
(3.44)\end{array}$ & $\begin{array}{r}0.00281 \\
(0.14)\end{array}$ & $\begin{array}{r}0.127^{* *} \\
(3.15)\end{array}$ & $\begin{array}{r}-0.109^{*} \\
(-2.54)\end{array}$ \\
\hline Share of export to GDP (\%) & $\begin{array}{r}0.00184 \\
(0.49)\end{array}$ & $\begin{array}{r}-0.00175 \\
(-0.66)\end{array}$ & $\begin{array}{r}0.00326 \\
(1.13)\end{array}$ & $\begin{array}{r}-0.0027 \\
(-0.45)\end{array}$ \\
\hline Regional dummy & $\begin{array}{r}-0.826^{*} \\
(-2.47)\end{array}$ & $\begin{array}{r}-0.540 * \\
(-2.52)\end{array}$ & $\begin{array}{l}-0.471 \\
(-1.47)\end{array}$ & $\begin{array}{l}0.608 \\
(1.28)\end{array}$ \\
\hline $\begin{array}{l}\text { Mid-point of observation period } \\
\text { (in quarters) }\end{array}$ & $\begin{array}{r}0.0877 \\
(1.36)\end{array}$ & $\begin{array}{r}0.121 * * * \\
(3.49)\end{array}$ & $\begin{array}{l}0.124 \\
(1.89)\end{array}$ & $\begin{array}{r}-0.0366 \\
(-0.40)\end{array}$ \\
\hline Restriction type (vara) & $\begin{array}{r}0.0578 \\
(0.43)\end{array}$ & $\begin{array}{r}0.0108 \\
(0.19)\end{array}$ & $\begin{array}{r}0.0104 \\
(0.08)\end{array}$ & $\begin{array}{l}-0.012 \\
(-0.07)\end{array}$ \\
\hline Restriction type (varb) & $\begin{array}{r}-0.0131 \\
(-0.06)\end{array}$ & $\begin{array}{r}0.0413 \\
(0.32)\end{array}$ & $\begin{array}{r}-0.22 \\
(-1.19)\end{array}$ & $\begin{array}{l}0.451 \\
(1.91)\end{array}$ \\
\hline Restriction type (varc) & $\begin{array}{r}-0.553 * * \\
(-2.63)\end{array}$ & $\begin{array}{r}-0.314^{*} \\
(-2.31)\end{array}$ & $\begin{array}{l}-0.175 \\
(-1.12)\end{array}$ & $\begin{array}{l}-0.158 \\
(-0.71)\end{array}$ \\
\hline Restriction type (vard) & $\begin{array}{l}-0.108 \\
(-0.60)\end{array}$ & $\begin{array}{r}-0.312 * * \\
(-2.71)\end{array}$ & $\begin{array}{r}0.441^{* * *} \\
(3.46)\end{array}$ & $\begin{array}{r}-0.696^{* * *} \\
(-3.67)\end{array}$ \\
\hline Quarterly data & $\begin{array}{l}0.247 \\
(1.30)\end{array}$ & $\begin{array}{l}0.116 \\
(0.97)\end{array}$ & $\begin{array}{l}-0.101 \\
(-0.64)\end{array}$ & $\begin{array}{r}1.058^{* * *} \\
(4.18)\end{array}$ \\
\hline Constant & $\begin{array}{r}-2.012^{*} \\
(-2.27)\end{array}$ & $\begin{array}{l}0.709 \\
(1.19)\end{array}$ & $\begin{array}{r}-1.35 \\
(-1.55)\end{array}$ & $\begin{array}{r}1.319 \\
(1.35)\end{array}$ \\
\hline
\end{tabular}

Meanwhile, the impact of the economic size is found significant and with a negative sign. The impact of the time-period of observation tends to decline over time. Also, differences in model specification across studies are found to have significant contributions in explaining variation of the output effects.

It is worth noting that although we have considered the importance of model dimension variable in our model, nonetheless based on a separate regression, we could not find any statistical evidences to support the arguments. We have also experimented using dummy variables to capture variation of interest rate used across studies, yet the results are insignificant. To capture temporal characteristics, there a wide ranging of temporal variables have been specified (see Subsection III.2.), nonetheless only the mid-point of observation period is found statistically significant. In the next section, however, our discussions will focus on the best specification results which fulfill model optimality criteria. 


\section{IV.2.1. Output effects and time paths of monetary policy actions}

Capital intensity - The coefficients of share of manufacturing and construction sector to GDP denote a positive (in absolute term) and significant effect in three different model specifications. ${ }^{46}$ This result suggests the importance of capital intensity in explaining variation of the output effects.

Capital intensive sectors may have a strong degree of sensitivity to the change of interest rate. This may be explained as follows. First, it relates to the cost channel or supply-side. As predicted by theory, an increase of the interest-rate will be followed by rise of production costs in the industrial sector, while its demand may respond in the opposite direction (demand-side effect $)^{47}$; in turn output will be falling. ${ }^{48}$ However, it is necessary to bear in mind that within this line of thinking, the concept of non-neutrality of money may prevail due to some type of rigidity.

Second, an increase in interest rates reduces demand for investment goods and (durable) consumer goods. When industries differ in their sensitivity to changes in the interest rate and regions differ in industrial composition, this theory is able to explain how a uniform monetary policy may generate differential regional effects. Carlino and DeFina (1998) and Hayo and Uhlenbrock (1999) found that industry mix has played key role in determining heterogeneous effects of the policy response across the US states, and German regions. ${ }^{49}$

In a similar vein, Barth and Ramey (2001) indicate that durable-goods industries in USA tend to be more responsive to monetary policy changes relative to the non-durable ones. In Europe, Ganley and Salmon (1997) and Dedola and Lippi (2005) ${ }^{50}$ also suggest that the durability of the output produced by the sector is an important determinant of its sensitivity to monetary policy changes. This is mainly because the demand for durable products, such as investment goods, is known to be much more affected by a rise in the interest rate through the usual costof-capital channel than the demand for non-durables such as food

Next, construction including the housing/property sector has typical regional characteristics particularly its spatial fixity ${ }^{51}$, hence may be a prominent driver in explaining volatility of regional

\footnotetext{
46 We follow Schunk (2005), to employ manufacturing share together with construction sector, as proxy for capital intensity measure. In addition to that Carlino and De Fina $(1996,1999)$ argued that some industries, such as manufacturing and construction, are highly sensitive to interest rates.

47 Manufacturing goods are conventionally known as income elastic products.

48 See previous discussion in Section 2.

49 As an illustration, an interest-sensitive sector i.e. manufacturing accounts for $27 \%$ of real gross state product (GSP) in the Great Lakes region, on average, during the 1985-1990 period, but less than 13\% of the Rocky Mountains region's real GSP (see Carlino and De Fina, 1999).

50 Earlier version was published on Servizio di Studi (2000) and C.E.P.R Discussion Paper (2000)

51 This terminology refers to the property market as a 'local goods', and thus immovable.
} 
output. One of the important sources of its volatility is strongly related to its high sensitivity to monetary policy changes. Fratantoni and Schuh (2003) assert that there is a close connection of housing investment with business cycles and monetary policy in the US states. ${ }^{52}$

In the standard literature, the relationship between the housing market and monetary policy is explained by the asset prices channel. As housing (including its land) is regarded as a type of equity, the channel can be interpreted both in terms of Tobin's $q$ theory and wealth effects. A rise in Tobin's $q$ for housing is initially induced by an increase in housing prices, which then raises their prices relative to replacement cost. Afterwards, its production will increase. Next, an increase of housing and land prices also will be translated into an increase of wealth, thereby raising consumption. Generally speaking, monetary policy changes will affect housing and land prices through aggregate demand side. ${ }^{53}$

Fratantoni and Schuh (2003) and Owyang and Wall (2004) have examined the role of regional housing markets in USA both from demand and supply side factors in explaining variations of monetary policy response. From demand side, disparities in regional sensitivity to changes in mortgage rates may reflect differences in consumption behavior, which can be indicated by a number of factors such as owner occupation rates, availability of equity, and the prevalence of buy-to-let mortgages. While, supply side factors identified include regional differences in availability of land, housing market regulation and proximity to urban centers.

As shown in the table, the coefficient of the share of manufacturing and construction sector to GDP on the maximum effect is about -0.02. The average estimated decrease of output following a one percentage increase of interest rate is 0.769 (see Appendix IV.1), so when the share of those sectors in an economy goes up by one percent, then the output effect will decline by about 2.60 percent. In other words, a capital intensive region will face more reductions in output following an increase in interest rate than a capital extensive one.

Meanwhile, the coefficient of the time-elapsed at maximum is about 0.02 . Following the above interpretation, it means when the share of manufacturing and construction sector in an economy increases by one percent, on average, time-speed to reach the full effect of monetary shocks on output will be longer by about 0.22 day (or, 5.28 hours).

Financial variable - As previously discussed, we employ several measures representing financial structure and financial development. In various specifications, only the share of credits to GDP (as a measure of level of financial development) is convincingly found positive (in absolute

52 Bernanke and Blinder (1992) indicate that there is a strong inverse lead-lag relationship between monetary policy, as measured by the federal funds rate or interest rate spreads (Friedman and Kuttner, 1993), and housing and other real activity.

53 Further details, see for instance, Mishkin (1995, 1996). 
term) and significant in most of all regressions. This result confirms that the regional differences in level of financial development play an important role in the differential transmission of monetary policy among sub national areas as well. ${ }^{54}$

The theoretical underpinning to explain a relationship between financial development and the variations of effect size may refer to the credit channel of monetary policy. The tighter monetary policy adversely affects asset prices, and hence collateral values, so impacts upon agents' ability to borrow. In turn, such credit constraints may impede aggregate demand, and thus impact negatively on output growth. Therefore, regions which have a lack capital, hence may rely more on external sources of bank-finance are likely to be more adversely affected if interest rates rise.

In addition, degree of accessibility to external funding may also vary among regions. The core region which has more access to different type of external funding may be less affected by interest rate changes than peripheral region. ${ }^{55}$ Therefore, we have used stock market capitalization as a key-measure of financial structure and hence able to represent the alternative funding source, however it is not confirmed by statistical results. Number of bank offices per 100.000 people that is also used as a measure of financial development is also found insignificant in determining regional differences of monetary transmissions. ${ }^{56}$

Meanwhile, the sixteenth quarter model that predicts the medium-term effects surprisingly does not show a significant result, as opposed to the short-run and the maximum effect model. This result may be mirroring the unfinished debate whether money has real effects in the shortrun, while it is neutral in the long run. ${ }^{57}$

From Table IV.1, the coefficient of the share of credits to GDP on the maximum effect is about -0.008 . Given the averaged output effect is 0.769 , then for every one percentage increase in the share of credit, on average, reduction of output following a one percentage increase in interest rate will increase by about 1.04 percent. Similarly, the coefficient of the time-elapsed at maximum is about 0.014; it suggests that the time-speed to reach the maximum effect of monetary shocks will be longer by about 0.15 day (or, equivalent to 3.65 hours).

Economic size - Coefficients of the economic size tend to indicate significant results and with negative sign (in absolute term) particularly in the maximum and medium-term model.

\footnotetext{
54 At the national level, numerous authors have found evidence supporting the importance of the banking sector for the transmission of monetary policy; Bernanke and Gertler (1995) provide an overview.

55 Ridhwan et al (2008) have also discussed differences in accessibility to external funding between two types of regions in more details.

56 This result is not shown, hence available upon request to the authors.

57 This argument may be rather preliminary or perhaps too simplistic. Therefore, we left behind this discussion in further for further research.
} 
Such result is not found for the short-term model. The minus sign suggests that small size economies are more adversely hit by a common (interest rate) shock than large economies. Some rationales of this argument could be elaborated as follows.

First, in order to reap gains from the global trade, small size economies might prepare themselves by specializing more in certain industries. As a result this specialization might be more prone to suffer from the uniform monetary shocks (Kalemli-Ozcan et al., 2001). Meanwhile, from a political side of bargaining position, larger economies are more likely able to influence a national economic policy, hence may be more synchronized in the aggregate business cycle, or less symmetry (Pons-Novell and Tirado-Fabregat, 2006).

Second, small economies generally may face larger shock impacts (output loss) relative to the larger economies, particularly related to their lower degree of resilience to the shock. This might be stemmed from their economic system limitations or the availability of adjustment mechanisms is less perfectly worked. Such limitations could be indicated by low level of saving accumulation, lack of institutional set-ups, larger fiscal constraints, supply-side bottlenecks and more dependent on external economies (foreign investment). On the contrary, the larger economies tend to have stronger capacity and more flexible mechanism in coping with the shock.

Third, addressing regional versus national levels, Alesina et al. (2005) also support the argument by mentioning the role of interregional risk-sharing and fiscal transfers with regions that face imperfectly uncorrelated shocks: "....larger countries are better able to provide insurance to regions affected by the common shocks...", and "... they can build distributive schemes in such a way able to channeling resources from richer to poorer regions."

In their study, GS is unable to get a significant regression result for economic size, so that they conclude that there is no differential output effect between small and large countries. Ehrmann (1998) on the other hand detects a substantial heterogeneity in the magnitude of the policy responses across European countries, with small responses in small economies are opposed to large reactions in large ones. ${ }^{58}$

The coefficient of economic size on the maximum effect is about 0.14. Given the average output effect is 0.769; so when the size of an economy increases by one percent higher relative to the others, then its output effect following a one percentage increase of interest rate will be lowered by about 18.21 percent. In other words, the larger the economy, the less output loss it will occur. Meanwhile, the negative coefficient of time-elapsed at maximum indicates that the larger the economy, the effects of monetary shocks will be faster than the lesser one.

58 Although, later he argued the asymmetric effects may not carry over after those countries join into the EMU, as new arbitrage opportunities lead to some degree of harmonization. 
Combining the two-effect findings, we may conclude, that larger economies are better off compared to small economies since the output loss is smaller. However, they may experience with full effects of the shock is much earlier than the smaller ones.

Degree of openness - Based on our regression model, export shares (in terms of goods and services) to GDP has a lack of statistical significance in determining differential monetary policy effects both in output size and time-speed.

Using the similar approach, Peersman and Smets (2002) and Dedola and Lippi (2005) were also failed to find any significant evidence that degree of openness was a factor in explaining heterogeneous responses. This result, however, might be caused by the fact that this measure is an indirect approach in illuminating the degree of openness particularly in the monetary (financial) area. Consequently, we may consider other types of openness measure that could directly capture cross-border financial transactions, and thus would be better in examining the links between degree of openness and the monetary policy shocks. ${ }^{59}$ This issue is left as a subject for further research.

Mid point of the observation period - This variable is only found significant in the fourth quarter model. This finding may suggest that the output effects of monetary policy tend to be weakening particularly within the time range of our study observation (between 1970's and 2000's).

Using a separate graphical analysis ${ }^{60}$, we also found that there is a tendency of shortening in time duration to reach the maximum output effect across studies. This finding tends to be consistent with the existing literatures and current phenomena. The role of better coordination in monetary and fiscal management (such as in the Euro area) and technological progress notably due to rapid development of the Information and Communication Technologies (ICTs) are notably the key-factors in speeding up the ripple effect of monetary shocks across regions and continents.

In terms of capturing study characteristics, Table IV.1 shows that type of model used (based on specific identification and restriction) in primary studies tend to be found significantly in explaining heterogeneities across studies particularly for varc and vard. The salient feature of

59 While, our study focuses on the role of interest rate as a prominent channel of monetary policy, the existing literature also posits exchange rate channel that may play a key role in determing the variations of policy effects. The higher relative interest rate inducing a capital inflow, which causes the exchange rate to appreciate, in turn results in a loss of competitiveness and thus, a decline in the demand for exports. Taking this impact on competitiveness through to external demand into account suggests that export intensive sectors regions would be more sensitive to monetary policy changes. Therefore, further separate investigation is needed to see whether exchange rate channel is able to capture this external effect.

60 For brevity, those graphs are not displayed 
the first identification scheme is that based on the structural VAR (SVAR) model with nonrecursive and long-run restrictions; 61 to the extent of such restrictions are claimed to have more theoretical contents rather than solely depend on the data. ${ }^{62}$

The latter restriction allows for the existence of cointegration, hence it can be specified as a vector error correction model, in turn it also provides information about long-run relationships between variables. It is worth noting that apart of the cointegration should be known, it should also content economic interpretations. Otherwise, imposing inappropriate cointegration relationships can lead to biased estimates (Ramaswamy and Slok, 1998).

Despite other restrictions are non significant, however, to our knowledge there is no such standard criteria is able to determine which identification scheme is superior relative to others; as different studies have different underlying approaches and economic reasons. To have a better understanding of this issue, thereby further studies in this field may be needed, yet it lies outside of the scope of this paper.

Regional dummy that is used to capture region specific characteristics is also found significant. Hence, it is quite consistent to the general beliefs, as the asymmetric effects of macroeconomic policy tends to be more apparent within a country than across countries, such as in Europe.

Furthermore, variation in time-frequency data is also able to capture such study differences. The significances of quarterly data instead of monthly data might indicate that there may be stronger relationship between interest rate changes and GDP (quarter based data) rather than with monthly data such as industrial production index. This may be reasonable considering that the first indicator covers much larger scope of economic activity both in terms of production and demand side; while the latter only consists of production indicator.

61 Ehrmann (2000) posits that the SVAR contents congruency advantage i.e. the accordance of a model with all the available evidence from all possible sources. This allows SVAR to have free systematic patterns in error terms as well as a well-specified model can be established.

62 The non-recursive structure is aimed to impose non-contemporaneous effect of monetary shock. As a practical consideration, in order to obtain an impact effect of interest rate innovations on the output, one has to put the latter after the interest rate; thereby monetary policy can not contemporaneously respond to output (further details, see Enders, 2004). 


\section{IV.3. Robustness checks}

In order to check robustness and reliability of our meta-regression results, we then recalculate our results from Table IV.1 (as benchmark) by using some weighting schemes as already discussed in Section IV.1. The robustness of our regression results could mainly be indicated by consistencies in coefficients across different specifications.

To account for quality of study, we assign journal-rank as a weight as shown in Table IV.2. Apparently the results of the four effect size remain unaltered compared to the benchmark regression in terms of sign, significance and size. Specifically, the main explanatory variables such as capital intensity, financial development, economic size, time period, and restriction type; all of them are significant. Assigning alternative weights related to degrees of freedom and sample-size, does not strongly affect the initial results. Therefore, taking all these findings altogether we may conclude that the benchmark regression tends to be robust.

\begin{tabular}{|c|c|c|c|c|}
\hline \multirow{3}{*}{$\begin{array}{l}\text { Dependent } \\
\text { variables }\end{array}$} & \multicolumn{3}{|c|}{$\begin{array}{c}\text { Table IV.2 } \\
\text { Different Weighting Schemes (1) }\end{array}$} & \\
\hline & \multirow[b]{2}{*}{ Independent variables } & \multicolumn{3}{|c|}{ Weighted } \\
\hline & & journal-rank & $\begin{array}{l}\text { degrees of } \\
\text { freedom }\end{array}$ & $\begin{array}{l}\text { sample } \\
\text { size }\end{array}$ \\
\hline 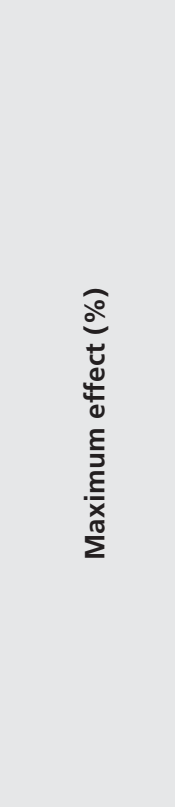 & $\begin{array}{l}\text { Share of manufacturing and } \\
\text { construction sector to GDP (\%) } \\
\text { Share of credit to GDP (\%) } \\
\text { Size of GDP } \\
\text { Share of export to GDP (\%) } \\
\text { Regional dummy } \\
\text { Mid-point of observation period } \\
\text { (in quarters) } \\
\text { Restriction type (vara) } \\
\text { Restriction type (varb) } \\
\text { Restriction type (varc) } \\
\text { Restriction type (vard) } \\
\text { Quarterly data } \\
\text { Constant }\end{array}$ & $\begin{array}{r}-0.009 \\
(-1.20) \\
-0.00879 * * \\
(-3.35) \\
0.109 * * \\
(2.68) \\
0.00404 \\
(1.17) \\
-0.361 \\
(-0.85) \\
0.164 * \\
(2.45) \\
-0.0994 \\
(-0.67) \\
-0.0854 \\
(-0.25) \\
-0.631 * * * \\
(-4.16) \\
-0.204 \\
(-1.33) \\
0.430 * * \\
(2.61) \\
-2.086 * \\
(-2.51)\end{array}$ & $\begin{array}{r}-0.0155^{*} \\
(-1.99) \\
-0.00536 \\
(-1.63) \\
0.112^{*} \\
(2.50) \\
0.00146 \\
(0.34) \\
-0.567 \\
(-1.58) \\
0.103 \\
(1.19) \\
0.137 \\
(0.81) \\
0.0156 \\
(0.07) \\
-0.547^{* *} \\
(-2.77) \\
-0.0807 \\
(-0.41) \\
0.222 \\
(1.18) \\
-1.952^{*} \\
(-2.09)\end{array}$ & $\begin{array}{r}-0.002 \\
(-0.21) \\
-0.00707^{*} \\
(-2.53) \\
0.103^{*} \\
(2.15) \\
-0.000198 \\
(-0.05) \\
-0.547 \\
(-1.76) \\
0.0296 \\
(0.41) \\
0.21 \\
(1.49) \\
0.388^{*} \\
(2.09) \\
-0.365^{*} \\
(-2.07) \\
0.0324 \\
(0.16) \\
0.191 \\
(1.25) \\
-2.210^{*} \\
(-2.19)\end{array}$ \\
\hline
\end{tabular}




\begin{tabular}{|c|c|c|c|c|}
\hline \multirow[b]{3}{*}{$\begin{array}{l}\text { Dependent } \\
\text { variables }\end{array}$} & \multicolumn{3}{|c|}{$\begin{array}{c}\text { Table IV.2 } \\
\text { Different weighting Schemes (1) - (continued) }\end{array}$} & \\
\hline & \multirow[b]{2}{*}{ Independent variables } & \multicolumn{3}{|c|}{ Weighted } \\
\hline & & journal-rank & $\begin{array}{l}\text { degrees of } \\
\text { freedom }\end{array}$ & $\begin{array}{l}\text { sample } \\
\text { size }\end{array}$ \\
\hline 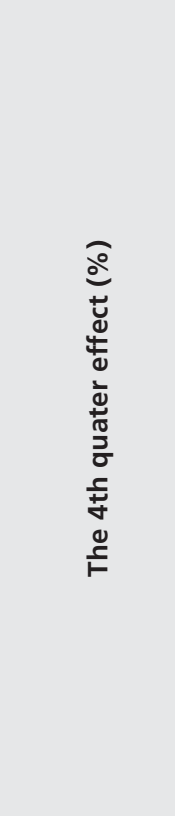 & $\begin{array}{l}\text { Share of manufacturing and } \\
\text { construction sector to GDP (\%) } \\
\text { Share of credit to GDP (\%) } \\
\text { Size of GDP } \\
\text { Share of export to GDP (\%) } \\
\text { Regional dummy } \\
\text { Mid-point of observation period } \\
\text { (in quarters) } \\
\text { Restriction type (vara) } \\
\text { Restriction type (varb) } \\
\text { Restriction type (varc) } \\
\text { Restriction type (vard) } \\
\text { Quarterly data } \\
\text { Constant }\end{array}$ & $\begin{array}{r}-0.0114^{*} \\
(-2.50) \\
-0.00408^{*} \\
(-2.60) \\
-0.0161 \\
(-0.66) \\
-0.00141 \\
(-0.69) \\
-0.181 \\
(-0.72) \\
0.177 * * * \\
(4.45) \\
-0.0705 \\
(-0.87) \\
-0.109 \\
(-0.54) \\
-0.278 * * \\
(-3.12) \\
-0.368 * * * \\
(-3.97) \\
-0.0258 \\
(-0.26) \\
0.94 \\
(1.89)\end{array}$ & $\begin{array}{r}-0.0138^{* *} \\
(-3.23) \\
-0.00259 \\
(-1.46) \\
-0.00824 \\
(-0.34) \\
-0.000821 \\
(-0.36) \\
-0.406^{*} \\
(-2.07) \\
0.134^{* *} \\
(2.81) \\
0.0152 \\
(0.18) \\
0.116 \\
(1.00) \\
-0.268 * * \\
(-2.61) \\
-0.331 * * \\
(-3.14) \\
0.172 \\
(1.66) \\
0.529 \\
(1.04)\end{array}$ & $\begin{array}{r}-0.0108^{*} \\
(-2.22) \\
-0.00361^{*} \\
(-2.12) \\
-0.00653 \\
(-0.23) \\
-0.00286 \\
(-1.19) \\
-0.421^{*} \\
(-2.21) \\
0.107^{*} \\
(2.40) \\
0.0483 \\
(0.62) \\
0.133 \\
(1.20) \\
-0.286^{*} \\
(-2.75) \\
-0.281^{*} \\
(-2.28) \\
0.0745 \\
(0.80) \\
0.6 \\
(0.98)\end{array}$ \\
\hline
\end{tabular}




\begin{tabular}{|c|c|c|c|c|}
\hline \multirow{3}{*}{$\begin{array}{l}\text { Dependent } \\
\text { variables }\end{array}$} & \multicolumn{3}{|c|}{$\begin{array}{c}\text { Table IV.2 } \\
\text { Different Weighting Schemes (2) }\end{array}$} & \\
\hline & \multirow{2}{*}{ Independent variables } & \multicolumn{3}{|c|}{ Weighted } \\
\hline & & journal-rank & $\begin{array}{l}\text { degrees of } \\
\text { freedom }\end{array}$ & $\begin{array}{l}\text { sample } \\
\text { size }\end{array}$ \\
\hline 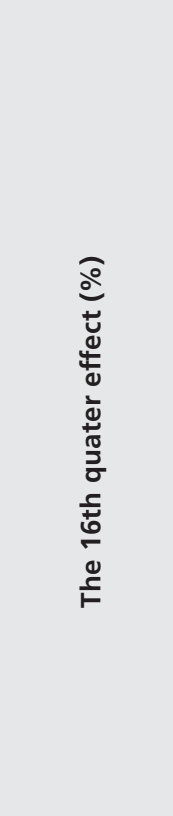 & $\begin{array}{l}\text { Share of manufacturing and } \\
\text { construction sector to GDP (\%) } \\
\text { Share of credit to GDP (\%) } \\
\text { Size of GDP } \\
\text { Share of export to GDP (\%) } \\
\text { Regional dummy } \\
\text { Mid-point of observation period } \\
\text { (in quarters) } \\
\text { Restriction type (vara) } \\
\text { Restriction type (varb) } \\
\text { Restriction type (varc) } \\
\text { Restriction type (vard) } \\
\text { Quarterly data } \\
\text { Constant }\end{array}$ & $\begin{array}{r}-0.0181^{*} \\
(-2.26) \\
-0.00630^{*} \\
(-2.29) \\
0.115^{* *} \\
(2.72) \\
0.00612 \\
(1.72) \\
-0.0572 \\
(-0.12) \\
0.137^{*} \\
(1.98) \\
-0.301^{*} \\
(-2.13) \\
-0.378 \\
(-0.96) \\
-0.243 \\
(-1.56) \\
0.323^{*} \\
(2.01) \\
-0.0648 \\
(-0.38) \\
-1.404 \\
(-1.62)\end{array}$ & $\begin{array}{r}-0.0234^{* *} \\
(-3.34) \\
-0.00511 \\
(-1.72) \\
0.134^{* * *} \\
(3.36) \\
0.00271 \\
(0.71) \\
-0.405 \\
(-1.23) \\
0.089 \\
(1.15) \\
0.0444 \\
(0.32) \\
-0.233 \\
(-1.20) \\
-0.115 \\
(-0.68) \\
0.480 * * \\
(2.80) \\
-0.0943 \\
(-0.55) \\
-1.607 \\
(-1.94)\end{array}$ & $\begin{array}{r}-0.013 \\
(-1.59) \\
-0.00186 \\
(-0.64) \\
0.0331 \\
(0.70) \\
0.00367 \\
(0.90) \\
0.0706 \\
(0.21) \\
0.0716 \\
(0.98) \\
-0.094 \\
(-0.74) \\
-0.0045 \\
(-0.02) \\
-0.152 \\
(-0.87) \\
0.501 \text { * } \\
(2.50) \\
-0.294 \\
(-1.88) \\
-0.262 \\
(-0.26)\end{array}$ \\
\hline 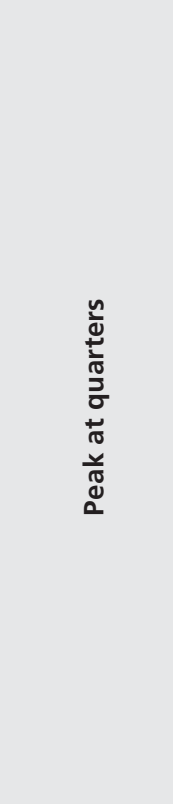 & $\begin{array}{l}\text { Share of manufacturing and } \\
\text { construction sector to GDP (\%) } \\
\text { Share of credit to GDP (\%) } \\
\text { Size of GDP } \\
\text { Share of export to GDP (\%) } \\
\text { Regional dummy } \\
\text { Mid-point of observation period } \\
\text { (in quarters) } \\
\text { Restriction type (vara) } \\
\text { Restriction type (varb) } \\
\text { Restriction type (varc) } \\
\text { Restriction type (vard) } \\
\text { Quarterly data } \\
\text { Constant }\end{array}$ & $\begin{array}{r}0.013 \\
(1.53) \\
0.0147^{\star * *} \\
(5.08) \\
-0.118^{\star *} \\
(-2.62) \\
-0.00236 \\
(-0.62) \\
0.581 \\
(1.25) \\
0.00154 \\
(0.02) \\
0.142 \\
(0.86) \\
0.437 \\
(1.17) \\
0.0336 \\
(0.20) \\
-0.650^{* * *} \\
(-3.85) \\
1.187 * * * \\
(6.53) \\
1.378 \\
(1.50)\end{array}$ & $\begin{array}{r}0.0164^{*} \\
(2.29) \\
0.0140^{* * *} \\
(4.66) \\
-0.0896^{*} \\
(-2.19) \\
-0.000823 \\
(-0.21) \\
0.663^{*} \\
(2.01) \\
-0.0558 \\
(-0.70) \\
0.0531 \\
(0.34) \\
0.407 * \\
(2.02) \\
-0.121 \\
(-0.67) \\
-0.734^{* * *} \\
(-4.08) \\
0.970^{* * *} \\
(5.60) \\
1.017 \\
(1.18)\end{array}$ & $\begin{array}{r}0.0220^{*} \\
(2.32) \\
0.0144^{* * *} \\
(4.34) \\
-0.0653 \\
(-1.15) \\
-0.00517 \\
(-1.10) \\
0.697 \\
(1.88) \\
-0.00433 \\
(-0.05) \\
-0.113 \\
(-0.67) \\
0.32 \\
(1.45) \\
-0.235 \\
(-1.13) \\
-0.779^{* *} \\
(-3.31) \\
0.868^{* * *} \\
(4.79) \\
0.524 \\
(0.44)\end{array}$ \\
\hline
\end{tabular}




\section{IV.4. Output Trajectory}

The outcomes of the meta-analysis can be used to sketch trajectories for different types of countries or regions (see Figure IV.6). We obtain a hump-shaped response pattern.

It appears that the size and timing of the effects tends to be larger and longer in the US states than in the European countries. This might be an indication that the US monetary policy tends to be more sensitive to monetary policy changes than the Euro zone. While previous discussions describe monetary transmissions from aggregate demand, differential effects of monetary policy could also be the result of regional differences in the supply curve. OECD (1999) has revealed that regional differences in the flexibility and institutional features of labor and product markets might also induce such differential effects. In addition, De Grauwe and Storti (2004) recently also suggest differences in sensitivity between the two monetary zones may be caused by differences in supply rigidities that tend to be more rigid in EU than in the US.

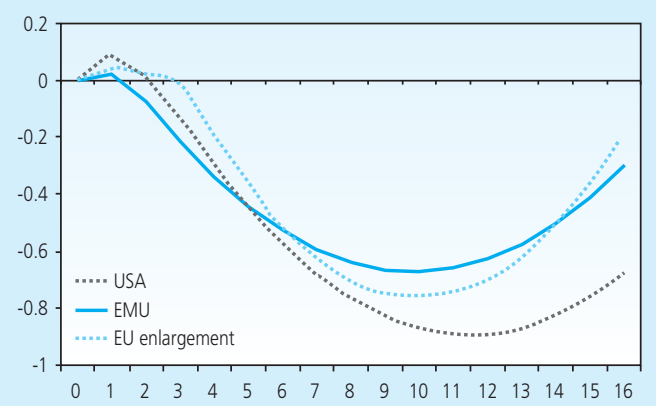

Figure IV.6The output paths following a contractionary monetary policy shock (reconstructed from parameters of meta-analysis)

Next, we will discuss size and timing of the monetary impacts from individual regions as follows. For a one percentage point of the unanticipated increase of interest rate, the average size of the effect after four quarters lies between -0.16 and -0.30 percent from baseline, whereas after sixteen quarters, the size of the effect on real output lies between -0.13 and -0.68 percent. Next, the maximum effect is in the range of -0.56 to -0.87 percent, and it occurs between 3 11 quarters after the shock imposed. ${ }^{63}$

63 As shown in Figure 6 especially for EU countries can be distinguished into EMU (eurozone) and EU enlargement. The latter group consists of accession countries notably Central and Eastern European countries and EU countries with free floating exchange rate regime (for more details, see: www.ecb.int; http://ec.europa.eu/index_en.htm). Additionally their interest rates set-up are anchored to interest rate in the euro area, and over time they tend to converge the euro's interest rate. 
From a geographical point of view, the maximum effect of the shock in the western part of EU countries (-0.59 percent) tends to be lower than in the eastern part (-0.72 percent). The timing to reach the highest impact takes longer in the west than in the east. ${ }^{64}$ These results seem to support the previous econometric findings that small size economies (east) may face larger output losses than in the west, while the reverse applies for the timing pattern. This dual pattern indicates a relatively close resemblance to the core-periphery phenomenon that is distinguished in the literature on asymmetric shocks. ${ }^{65}$

\section{CONCLUSION}

In this paper we establish based on a meta-analysis of available evidence a set of stylized facts about the real effects of monetary policy at the regional level, particularly in the US and Europe. Our meta analysis results unravel convincingly the importance of capital intensity (structural composition) and credit (financial development) in playing key roles for regional developments.

Additionally, while there are no prior beliefs of how disparate impact of monetary shocks may relate to the size of economy, here it is quite convincingly found that a small size economy may experience larger output loss in response to a monetary contraction than does the larger one. Hence, this phenomenon may assert a core-periphery pattern especially among the European countries. ${ }^{66}$

Furthermore, given the nature of monetary policy conduct is uniformly undertaken at a national level, while simultaneously the potential distributional implications may also arise amongst regions, it may be still relevant to ask what monetary policy can do for (regional) economic development; as a credible monetary policy could do more rather than formulating an interest rate to achieve the national inflation target.

From our findings here, we would argue that the national policymaking process particularly for economic (inflation) forecasts as well as the impact of the policy ${ }^{67}$ could be improved by considering its disparate impacts on regional activity. By the same token, Aksoy et al. (2002) argue that the use of majority voting by the ECB in formulating a common policy may bring potential significant conflicts between member states in an environment characterized by

64 The size of the effect after four quarters and sixteen quarters between two areas is about the same.

65 Previously Artis and Zhang (1998a, 1998b) among others have indicated there is a tendency of core-periphery pattern among European countries.

66 Hallett and Piscitelli (1999) provide a complete treatment of the asymmetric effects based on differences in the monetary transmissions, the wage/price transmissions and private sector asset holdings.

67 The best practices of monetary policy implementations are currently based on the forward-looking rule. 
asymmetric shocks, and hence they propose other decision rules in which consensus plays a greater role. Implicitly it posits more balanced power across the board given variations in characteristics of the states or regions. To this end, we left the latter issue of how an effective monetary policy should be undergone both in meso (regional) and micro (firms, household, etc) level in more details for further research. 


\section{REFERENCES}

Abreu, M., de Groot, H.L.F. and Florax, R.J.G.M. (2005) A meta-analysis of -convergence: the legendary 2\%. Journal of Economic Surveys 19, 389-420.

Altavilla, C. (2000) Measuring monetary policy asymmetries across EMU countries. Katholieke Universiteit Leuven, Discussion Paper no. 22.

Anzuini, A. and Levy, A. (2007) Monetary policy shocks in the new EU members: A VAR approach. Applied Economics 39, 9, 1147-1162.

Alesina, A., Spolaore, E. and Wacziarg, R. (2005) Trade, growth and the size of countries. In: Aghion, P. and Durlauf, S. (eds), Handbook of Economic Growth. North Holland: Elsevier. Aksoy, Y., De Grauwe, P., and Dewachter, H. (2002) Do asymmetries matter for European monetary Policy? European Economic Review 46, 443-469.

Artis M.J. and Zhang, W. (1998a) Core and periphery in EMU: a cluster analysis. European University Institute, RSC Working Papers no. 98/37.

Artis M.J. and Zhang, W. (1998b) Membership of EMU: a fuzzy clustering analysis of alternative criteria. European University Institute, RSC Working Papers no. 98/52.

Baldwin, R.E. and Wyplosz, C. (2004) The Economics of European Integration. New York: McGraw-Hill.

Barth III, M. J. and. Ramey, V. A. (2001) The cost channel of monetary transmission. NBER Macroeconomics Annual 16, 199-240.

Beck, T., Levine, R. and Loayza, N. (2000) Financial intermediation and growth: Causality and causes. Journal of Monetary Economics 46, 1, 31-77.

Bernanke, B. S. and Blinder, A. S. (1992) The federal funds rate and the channels of monetary transmission. The American Economic Review 82, 4, 901-21.

Bernanke, B.S. (1986) Altenative explanations of money-income correlation.

Carnegie-Rochester Conference Series on Public Policy 25, 49-100.

Bernanke, B.S. and Gertler, M. (1995) Inside the black box, the credit channel of monetary policy transmission. Journal of Economic Perspectives 9, 27-48.

Blanchard, O. J. and D. Quah. (1989) The dynamic effects of aggregate demand and supply disturbances. The American Economic Review 79, 4, 655-73. 
Bösch, H. (2004). Reanalyzing a meta-analysis on extra-sensory perception dating from 1940, the first comprehensive meta-analysis in the history of science. In S. Schmidt (Ed.), Proceedings of the 47th Annual Convention of the Parapsychological Association, University of Vienna, (pp. 1-13)

Card, D. and Krueger, A. B. (1995) Time-series minimum-wage studies: a meta-analysis. The American Economic Review 85, 238-43.

Carlino, G. and De Fina, R.H. (1998) The differential regional effects of monetary policy. Review of Economics and Statistics 80, 572-587.

Carlino, G. and De Fina, R.H. (1999) The differential regional effects of monetary policy: evidence from the U.S. States. Journal of Regional Science 39, 339-358.

Cecchetti, S. G. (1999) Legal structure, financial structure, and the monetary policy transmission mechanism. National Bureau of Economic Research, Working Paper no.-7151.

Clements, B.,

Kontolemis, Z., Levy, J., and Joaquim, V. (2001) Monetary Policy under EMU: Differences in the transmission mechanism. IMF, Working Paper no. 01/102.

Cover, J.P. (1992) Asymmetric effects of positive and negative money-supply shocks. The Quarterly Journal of Economics 107, 4, 1261-1282.

Dedola, L. and Lippi, F. (2005) The monetary transmission mechanism: Evidence from the industries of five OECD countries. European Economic Review 49, 1543-69.

De Grauwe, P. (1994) The Economics of Monetary Integration. Oxford: Oxford University Press.

De Grauwe, P. and Storti, C. C. (2004) The effects of monetary policy: a meta-analysis CESIFO, Working Paper no. 1224.

De Long, J. B., Summers, L. H., Mankiw, N. G. and Romer, C. D. (1988) How Does Macroeconomic Policy Affect Output? Brookings Papers on Economic Activity 2, 433-494. Ehrmann, M. (1998) Will EMU generate asymmetry? Comparing monetary policy transmission across European countries. EUI, Working Paper no.28.

Elbourne, A. and de Haan, J. (2004) Asymmetric Monetary Transmission in EMU: The Robustness of VAR Conclusions and Cecchetti's Legal Family Theory. CESIFO, Working Paper no. 1327. Enders, W. (2004). Applied Econometrics Time Series. Hoboken, NJ: John Wiley and Sons.

Faust, J. (1998) The robustness of identified VAR conclusions about money. Carnegie-Rochester Conference Series on Public Policy 49, 207-244.

Fishkind, H.H. (1977) The regional impact of monetary policy: an economic simulation study of Indiana (1958-1973). Journal of Regional Science 17, 77-88.

Florax, R. J. G. M., Groot, H. L. F. and Mooij, R. A. (2002) Meta-analysis: a tool for upgrading inputs of macroeconomic policy models. Tinbergen Institute, Discussion Papers no. 041/3. 
Florio (2004) The asymmetric effects of monetary policy. Journal of Economic Surveys 18, 3 , 409-426.

Frantantoni, M. and Schuh, S. (2003) Monetary policy, housing, and heterogeneous regional markets. Journal of Money, Credit and Banking 35, 557-589.

Ganley, J., and Salmon, C. (1997) The industrial impact of monetary policy shocks: some stylised facts. Bank of England, Working Paper no. 68.

Gali, J. (1992) How well does the IS-LM model fit postwar US data? The Quarterly Journal of Economics, 107, 2, 709-38.

Gali, J. (1999) Technology, employment, and the business cycle: do technology shocks explain aggregate fluctuations? American Economic Review 89, 1, 249-71.

Garrison, C.B. and Chang, H.S. (1979) The effect of monetary and fiscal policies on regional business cycles. International Regional Science Review 4, 167-180.

Gerlach, S. and Smets, F. (1995) The monetary transmission mechanism: evidence from the G7 countries. BIS, Working Paper no. 26.

Gorg, H. and Strobl, E. (2001) Multinational companies and productivity spillovers: a metaanalysis. Economic Journal 111, 475, 723-39.

Greene, W. H. (2000) Econometric Analysis. New Jersey: Prentice Hall Upper Saddle River.

Guiso, L., Kashyap, A. K., Panetta, F. and Terlizzese, D. (2000) Will a common European monetary policy have asymmetric effects? Economic Perspectives 4, 56-75.

Gujarati, D. N. (2003) Basic Econometrics. New York: McGraw-Hill.

Hallet, A.H. and Piscitelli, L. (1999) EMU in reality: The effect of a common monetary policy on economies with different transmission mechanisms. Empirica 26, 4, 337-358.

Homes, M.J. (2000) Monetary shocks and the asymmetric adjustment of UK regional output. Environment and Planning C: Government and Policy 18, 667-680.

Karras, G. (1996) Are the output effects of monetary policy asymmetric? Evidence from a sample of European countries. Oxford Bulletin of Economics and Statistics 58, 2, 267-278.

Keef, S.P. and Roberts, L.A. (2004). The meta-analysis of partial effect sizes. British Journal of Mathematical and Statistical Psychology 57, 1, 97-129.

Kalaitzidakis, P., Mamuneas, T. P. and Stengos, T. (2003) Rankings of academic journals and institutions in economics. Journal of the European Economic Association 1, 6, 1346-66.

Kennedy, P. (2008) A Guide to Econometrics. Oxford: Blackwell Publishing,.

Kieler, M., and Saarenheimo, T. (1998). Differences in monetary policy transmission?: a case not closed. European Commission Economic Papers 2, 407.

King, R. G ., Plosser, C.I., Stock, J.H., and Watson, M.W. (1991) Stochastic trends and economic fluctuations. The American Economic Review 81, 4, 819-40. 
King, R. G. and Levine, R. (1993) Finance and growth: Schumpeter might be right. The Quarterly Journal of Economics 108, 3, 717-37.

Kiviet, B., Elbourne, A. and de Haan, J. (2003) Financial structure and monetary policy transmission in transition countries. Rijksuniversiteit Groningen Working Paper.

Knell, M., and Stix, H. (2003) The Income Elasticity of Money Demand: A Meta-analysis of Empirical Results. Journal of Economic Surveys 19, 3, 513-33.

Koetse, M. J., Florax, R. J. G. M. and de Groot, H. L. F. (2005) Correcting for primary study misspecifications in meta-analysis. Tinbergen Institute, Discussion Papers no. 05/029.

Krueger, A. B. (2003) Economic considerations and class size. Economic Journal 113, 34-63.

Leeper, E. M., Sims, C.A., and Zha, T. (1996) What does monetary policy do? Brookings Papers on Economic Activity 2, 1-63.

Levine, R. (1997) Financial development and economic growth: Views and agenda. Journal of Economic Literature 35, 688-726.

Mankiw, N.G. (1997)-Macroeconomics. New York: Worth Publishers.

Mihov, I. (2001) One monetary policy in EMU. Economic Policy, 33, 369-406.

Miller, R.J. (1978) The Regional Impact of Monetary Policy in the United States. Lexington, MA: Lexington Books.

Mishkin, F. (1995) Symposium on the Monetary Transmission Mechanism. Journal of Economic Perspectives 9, 3-10.

Mishkin, F. S. (1996) The channels of monetary transmission: lessons for monetary policy. National Bureau of Economic Research, Working Paper no. 5464.

Mojon, B., and Peersman, G. (2001) A VAR description of the effects of monetary policy in the individual countries of the euro area. European Central Bank, Working Paper no. 92.

Nijkamp, P. and Poot, J. (2004) Meta-analysis of the effect of fiscal policies on long-run growth. European Journal of Political Economy 20, 1, 91-124.

Organisation for Economic Cooperation and Development (1999) EMU, Facts, Challenges and Policies. Paris: OECD.

Owyang, M.T. and Wall, H.J. (2004) Structural breaks and regional disparities in the transmission of monetary policy. Federal Reserve Bank of St. Louis, Working Paper no. 2003-008C.

Pearson, Karl, (1904), Mathematical contributions to the theory of evolution.

Peersman, G. (2004) The transmission of monetary policy in the Euro Area: are the effects different across countries? Oxford Bulletin of Economics and Statistics 66, 3, 285-308.

Pitzel, D., and Uuskula, L. (2005) The effect of financial depth on monetary transmission. Eesti Bank, Working Papers no. 10. 
Ridhwan, M. M., Nijkamp P., Rietveld, P. and de Groot, H. L. F. (2008) Regional development and monetary policy: a review of the role of monetary unions, capital mobility and locational effects. VU Amsterdam, Research Memoranda no. 0007.

Rose, A. K. and T. D. Stanley. (2005) A meta-analysis of the effect of common currencies on international trade. Journal of Economic Surveys 19,3, 347-65.

Romer, D. (1996). Advanced Macroeconomics. New York: McGraw-Hill Companies-Inc.

Schunk, D. (2005) The differential impacts of monetary policy: are the differences diminishing? Papers in Regional Science 84, 1, 127-36.

Shapiro, M. D. and Watson, M. W. (1988) Sources of business cycle fluctuations. NBER Macroeconomic Annual 3, 111-48.

Sims, C.A. (1980) Macroeconomics and reality. Econometrica 48, 1-48.

Sims, C.A. (1986) Are forecasting models usable for policy analysis.

Federal Reserve Bank of Minneapolis Quarterly Review (Winter edition), 3-16.

Smith, V. K. and J. C. Huang. (1995) Can markets value air quality? A meta-analysis of hedonic property value models. Journal of Political Economy 103, 209-27.

Stanley, T. D. (2005) Beyond publication bias. Journal of Economic Surveys 19, 3, 309-45.

Stanley, T. D. and Jarrell, S.B. (1989) Meta-Regression Analysis: a Quantitative Method of Literature Surveys. Journal of Economic Surveys 19, 3, 299-308.

Sutton, A.J., Abrams, K.R., Jones, D.R., Sheldon, T.A. and Song, F. (2000) Methods for MetaAnalysis in Medical Research. Chichester: John Wiley \& Sons.

Taylor, J. (1995) The monetary transmission mechanism: an empirical framework. Journal of Economic Perspectives 9, 11-26.

Weichselbaumer, D. and R. Winter-Ebmer. (2005) A meta-analysis of the international wage gender gap. Journal of Economic Surveys 19, 3, 479-511.

White, H. (1984) Asymptotic Theory for Econometricians. Orlando: Academic Press. 
Appendix IV.1

Descriptive statistics of all candidate variables used in the meta-analysis regression

\begin{tabular}{|c|c|c|c|c|c|c|}
\hline & Variable & Obs & Mean & Std. Dev & Min & Max \\
\hline 1. & $\begin{array}{l}\text { Dependent variables } \\
\text { Output effect of monetary shock in the } 4 \text { th quarter (short-run effect) } \\
\text { Output effect of monetary shock in the 16th quarter (medium-run effect) } \\
\text { Output effect of monetary shock at the maximum level (maximum effect) } \\
\text { Time-elapsed at the maximum effect }\end{array}$ & $\begin{array}{l}185 \\
179 \\
171 \\
170\end{array}$ & $\begin{array}{l}-0.3108 \\
-0.4967 \\
-0.7687 \\
8.2763\end{array}$ & $\begin{array}{l}0.3693 \\
0.6216 \\
0.6377 \\
4.4882\end{array}$ & $\begin{array}{c}-1.8750 \\
-2.8650 \\
-2.9400 \\
0.3330\end{array}$ & $\begin{array}{c}1.6190 \\
0.6860 \\
0.0300 \\
20.0000\end{array}$ \\
\hline 2. & $\begin{array}{l}\text { Restriction type and data characateristics } \\
\text { Dummy for identification and restriction scheme } \\
\text { - VAR -Choleski decomposition and recursive (Sims,1980) } \\
\text { - Structural VAR with non recursive contemporaneous restriction } \\
\text { Bernanke-Blinder, 1992) } \\
\text { - Structural VAR with long-run restricitions (Blanchard and Quah, 1989) } \\
\text { - Combination of short-run and long-run restrictions (Gali, 1992, 1999) } \\
\text { - VAR with cointegration factor (King et al., 1991) } \\
\text { Dummy for model dimension : } \\
\text { - Basic form (four variables: price, output, interest rate and } \\
\text { money supply/credit) } \\
\text { - Basic form with exchange rate added } \\
\text { - Basic form with exchange rate, commodity price and foreign } \\
\text { interest rate added } \\
\text { Dummy output variable : } \\
\text { - GRDP (gross regional domestic products) or GDP } \\
\text { - total personal income } \\
\text { - Industrial production index } \\
\text { Number of degrees of freedom } \\
\text { Sample size } \\
\text { Journal rank } \\
\text { Temporal characteristics: } \\
\text { Year of publication } \\
\text { Mid point of observation period } \\
\text { Initial year of the sample } \\
\text { End of period the sample } \\
\text { Time frequency data (monthly) } \\
\text { Time frequency data (quarterly) } \\
\text { Dummy in decade: } \\
\text { Dummy for the } 1960 \text { 's data used in the study } \\
\text { Dummy for the 1970's data used in the study } \\
\text { Dummy for the 1980's data used in the study } \\
\text { Dummy for the 1990's data used in the study } \\
\text { Length of observation period in the study (in quarters) } \\
\text { Length of time-lag used in the sample (in quarters) }\end{array}$ & $\begin{array}{l}185 \\
185 \\
185 \\
185 \\
185 \\
185 \\
\\
185 \\
185 \\
185 \\
185 \\
185 \\
185\end{array}$ & $\begin{array}{c}2000.838 \\
1983.792 \\
1972.4760 \\
1995.1080 \\
0.1568 \\
0.8432 \\
\\
0.0432 \\
0.3351 \\
0.2865 \\
0.3351 \\
103.1027 \\
3.1135\end{array}$ & $\begin{array}{c}2.634569 \\
8.543443 \\
12.5326 \\
6.3348 \\
0.3646 \\
0.3646 \\
\\
0.2040 \\
0.4733 \\
0.4533 \\
0.4733 \\
37.7718 \\
0.9167\end{array}$ & $\begin{array}{c}1995 \\
1969 \\
1958 \\
1978 \\
0.0000 \\
0.0000 \\
\\
0.0000 \\
0.0000 \\
0.0000 \\
0.0000 \\
42.0000 \\
1.0000\end{array}$ & $\begin{array}{c}1.0000 \\
1.0000 \\
1.0000 \\
1.0000 \\
228.0000 \\
5.0000\end{array}$ \\
\hline 3. & $\begin{array}{l}\text { Conditioning variables } \\
\text { Capital intensity measure (total shares of manufacturing } \\
\text { and construction sectors to GDP) } \\
\text { Share of manufacturing sector (\% of GDP) } \\
\text { Share of construction sector (\% of GDP) } \\
\text { Economic size (GDP in US dollars) in Log. } \\
\text { Percents of export to GDP } \\
\text { Share of bank-credits disbursed to private institutions (\% to GDP) } \\
\text { Number of bank-offices per } 100.000 \text { people (in log) } \\
\text { Stock market capitalization (\% of GDP) } \\
\text { Dummy for floating exchange rate regime } \\
\text { Dummy for pegged exchange rate regime } \\
\text { Population size or number of people (in log) } \\
\text { Geographical and temporal characteristics: } \\
\text { Country-level dummy } \\
\text { Regional-level dummy } \\
\text { USA dummy } \\
\text { Eurozone (EMU) dummy } \\
\text { European union (non-eurozone) dummy }\end{array}$ & $\begin{array}{l}185 \\
185 \\
185 \\
185 \\
185 \\
185 \\
185 \\
185 \\
185 \\
185 \\
185\end{array}$ & $\begin{array}{c}35.3547 \\
28.0749 \\
7.2798 \\
18.8570 \\
24.0872 \\
57.4745 \\
34.5494 \\
50.2907 \\
0.5351 \\
0.4649 \\
16.2485\end{array}$ & $\begin{array}{c}10.8232 \\
8.7990 \\
4.4852 \\
1.3665 \\
19.0209 \\
31.2479 \\
16.9597 \\
29.1044 \\
0.5001 \\
0.5001 \\
1.3434 \\
\\
0.4968 \\
0.4968 \\
0.4968 \\
0.4912 \\
0.3745\end{array}$ & $\begin{array}{c}9.6600 \\
3.6000 \\
3.4800 \\
15.6338 \\
6.5700 \\
15.2500 \\
2.1890 \\
2.8200 \\
0.0000 \\
0.0000 \\
12.8064\end{array}$ & $\begin{array}{c}60.2660 \\
39.8900 \\
30.1330 \\
21.4003 \\
74.1700 \\
120.2400 \\
95.9000 \\
129.5400 \\
1.0000 \\
1.0000 \\
18.2228\end{array}$ \\
\hline
\end{tabular}

